\title{
Retrospective Evaluation of the Effectiveness of Superior Hypogastric Plexus Block in Chronic Pelvic Pain
}

\section{Kronik Pelvik Ağrıda Superior Hipogastrik Pleksus Blok Etkinliğinin Retrospektif Değerlendirilmesi}

\author{
Dostali Aliyev, Umit Akkemik, Ibrahim Asik \\ Ankara University, Faculty of Medicine, Department of Anesthesiology and Reanimation, Division of Algology, Ankara, Turkey
}

\section{ABSTRACT}

Objective: Chronic pain is a cause that negatively affects the quality of life and functional capacity. As with most chronic pain syndromes, chronic pelvic pain requires a multimodal approach. Hypogastric plexus blockade and neurolysis may be effective in cases that do not respond to conservative treatments. In this study, we retrospectively evaluated the effect of hypogastric plexus blockade in patients with chronic pelvic pain.

Methods: Forty patients with chronic pelvic pain (duration of pain> 6 months) who underwent hypogastric plexus block under fluoroscopy were evaluated retrospectively. Neurolysis was performed after diagnostic block in 19 patients with chronic pelvic pain associated with pelvic cancer.

Results: While the visual analogue scale (VAS) of the patients who underwent superior hypogastric block was 8.8 before the procedure, the VAS scores at 1 month, 3 months and 6 months after the procedure were recorded as 3.7, 2.2, and 1.1, respectively $(p<0.05)$. While the mean Oswestry Disabilty Index (ODI) score of the patients before the procedure was $46.0 \%$ (severe disability), it was recorded as $3 \%$ at the $6^{\text {th }}$ month. The changes in VAS and ODI scores were statistically significant $(p<0.05)$.

Conclusion: Hypogastric plexus blockade should be considered as an effective treatment option in the treatment of chronic pelvic pain.

Keywords: Pelvic pain, nerve block, pain management, chemical neurolysis, fluoroscopy

\section{öz}

Amaç: Kronik ağrı hayat kalitesi ve fonksiyonel kapasiteyi olumsuz etkileyen bir nedendir. Kronik ağrı sendromlarının pek çoğunda olduğu gibi kronik pelvik ağrı da multimodal yaklaşım gerektirir. Konservatif tedavilere yanıt vermeyen olgularda hipogastrik pleksus blokajı ve nörolizis etkin olabilmektedir. Bu çalışmada, kronik pelvik ağrılı olgularda superior hipogastrik pleksus blokajının etkinliğini retrospektif olarak değerlendirdik.

Yöntem: Kronik pelvik ağrısı (ağrı süresi>6 ay) olan ve floroskopi rehberliğinde superior hipogastrik pleksus blokajı yapılmış 40 hasta retrospektif olarak değerlendirilmiştir. Pelvik kanser ilişkili kronik pelvik ağrısı olan 19 hastada diagnostik blok sonrası nörolizis uygulanmıştir.

Bulgular: Superior hipogastrik blok uygulanan hastaların vizüel analog skalası (VAS) işlem öncesi 8,8 iken işlemden 1 ay, 3 ay ve 6 ay sonraki VAS skorları sırasıyla 3,7, 2,2, 1,1 olarak kaydedilmiştir $(p<0,05)$. İşlem öncesi hastaların ortalama Oswestry Disabilite İndeksi (ODI) skoru \%46,0 (ağır özürlülük) iken 6. ayda \%3 olarak kaydedilmiştir. Vizuel analog skala ve ODI skorlarındaki değişimler istatistiksel olarak anlamlı bulunmuştur $(p<0,05)$.

Sonuç: Kronik pelvik ağrı tedavisinde superior hipogastrik pleksus blokajı etkin tedavi seçenekleri arasındadır.

Anahtar sözcükler: Pelvik ağrı, sinir bloğu, ağrı yönetimi, kimyasal nörolizis, floroskopi

\section{INTRODUCTION}

Chronic pelvic pain (CPP) is defined as persistent pain in the lower abdomen or pelvis that persists for at least 6 months and exists outside of menstruation, pregnancy or intercourse (1). It is often associated with negative cognitive, behavioral, sexual and emotional problems, gynecological, urinary system, pelvic floor and intestinal dysfunctions (2). Chronic pelvic pain can originate from various etiologies such as endometriosis, pelvic inflammatory disease, pelvic masses and surgery in the pelvis. According to the World Health Organization reports, the global prevalence of CPP is estimated to be between $5.7 \%$ and $26.6 \%$ (3).
Received/Geliş tarihi : 03.10.2021 Accepted/Kabul tarihi : 23.12.2021 Publication date 28.01.2022
*Corresponding author: Dostali Aliyev • dr.dostalialiyev@gmail.com

Dostali Aliyev (ㄷ) 0000-0002-6111-0938 / Umit Akkemik 다 0000-0001-8483-5416

Ibrahim Asik (D) 0000-0002-4800-3150 
Chronic pelvic pain management requires a multimodal approach. In cases where conservative treatments such as psychosocial support and behavioral treatments, pharmacological and physical therapy cannot be effective, interventional pain and surgical methods are applied.

The superior hypogastric plexus is located to the left of the midline, just below the aortic bifurcation, anterior to the $L 5$ vertebral body. At the level of the L5-S1 disc, the sympathetic branches separate and descend towards the pelvis, forming the inferior hypogastric plexus. In addition to the urethra, bladder, rectum, sigmoid and descending colon, it provides innervation of testis and prostate in men, vagina, uterus and ovaries in women (4). The main indication for superior hypogastric nerve block is visceral pelvic pain refractory to medical therapy. It was first applied by Plancarte in 1989 in the treatment of malignant pain with the double needle posterolateral approach (5).

In our study, we aimed to retrospectively evaluate the efficacy of the procedure in patients with chronic pelvic pain in whom conservative treatments could not yield effective results and who underwent fluoroscopy guided superior hypogastric plexus blockade.

\section{MATERIAL and METHODS}

Ethics committee approval was obtained for the study (Decision No 15-303-21, dated 21.05.2021). Patients aged 18 years and older, with a visual analogue scale (VAS) of $\geq 4$ and who underwent superior hypogastric plexus block, who were followed up in the Pain Outpatient Clinic with the diagnosis of chronic pelvic pain between 31 October 2018-2020 were included in the study. Patients younger than 18 years of age, with VAS $<4$, and patients with missing post-procedure records were excluded from the study.

We reached the patient records by scanning the electronic database of our hospital and the pain follow-up forms in our clinic. We completed the missing information in the files or in the electronic system by calling the patients by phone and obtaining their consent for the retrospective study.

Age, gender and body-mass index (BMI) of the patients were recorded. Visual Analogue Scale and Oswestry Disability Index (ODI) scores were recorded before and at 1, 3, and 6 months after the procedure.

Superior hypogastric plexus block can be performed with classical and transdiscal techniques (6). The classical approach with a $22 \mathrm{G}$ needle is applied in our clinic. After providing routine monitoring, sedoanalgesia, asepsis and antisepsis in the prone position, the $\mathrm{C}$ arm of the fluoroscopy is brought to the antero-posterior position. L4-L5 intervertebral disc is marked under fluoroscopy. A point is marked as the insertion site of the needle at a distance of $7 \mathrm{~cm}$ lateral to both sides from the midline of the L4-5 range. Local anesthesia is applied to these points with $2 \mathrm{~mL}$ of $2 \%$ lidocaine. With classical approach, a $15 \mathrm{~cm}, 22 \mathrm{G}$ needle is first guided 30 degrees caudally and 45 degrees towards the lower end of the $L 5$ vertebral body at the midline. Then the needle is placed on the other side in the same way. In the lateral view, both needles should be at the anterior lower end of the L5-S1 junction. Then $3 \mathrm{~mL}$ of contrast dye is given. In the antero-posterior view, the dye ought to be confined to the midline area without spread laterally and ought to remain in the area without washout on subsequent images (Figure 1). On the lateral view, the contrast dye should appear as a thin line (Figure 2).

After the negative aspiration test, a total of $5 \mathrm{~mL}$ of $0.25 \%$ bupivacaine or $1 \%$ lidocaine with $25 \mathrm{mg}$ of triamcinolone or $40 \mathrm{mg}$ of methylprednisolone is administered through each needle. Neurolytic block (4-6 mL of $6 \%-8 \%$ phenol solution) can be administered to patients with persistent pain (eg cancer-related) who benefit from diagnostic block (50\% reduction in VAS).

\section{Statistical Analysis}

Descriptive statistics were presented as mean \pm standard deviation or median (minimum-maximum) according to fitness for normal distribution for quantitative variables, and frequency (percent) for qualitative variables. Friedman test was used to compare VAS and ODI scores with repeated measure-

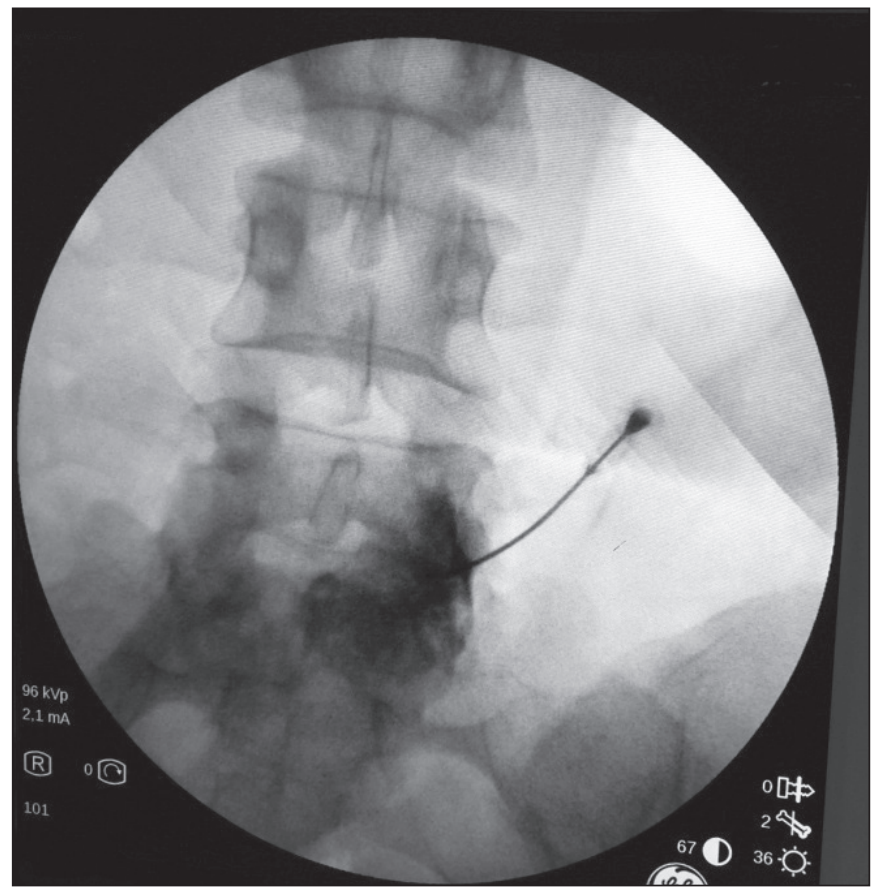

Figure 1: Final needle position and spread of contrast in anteroposterior view. 


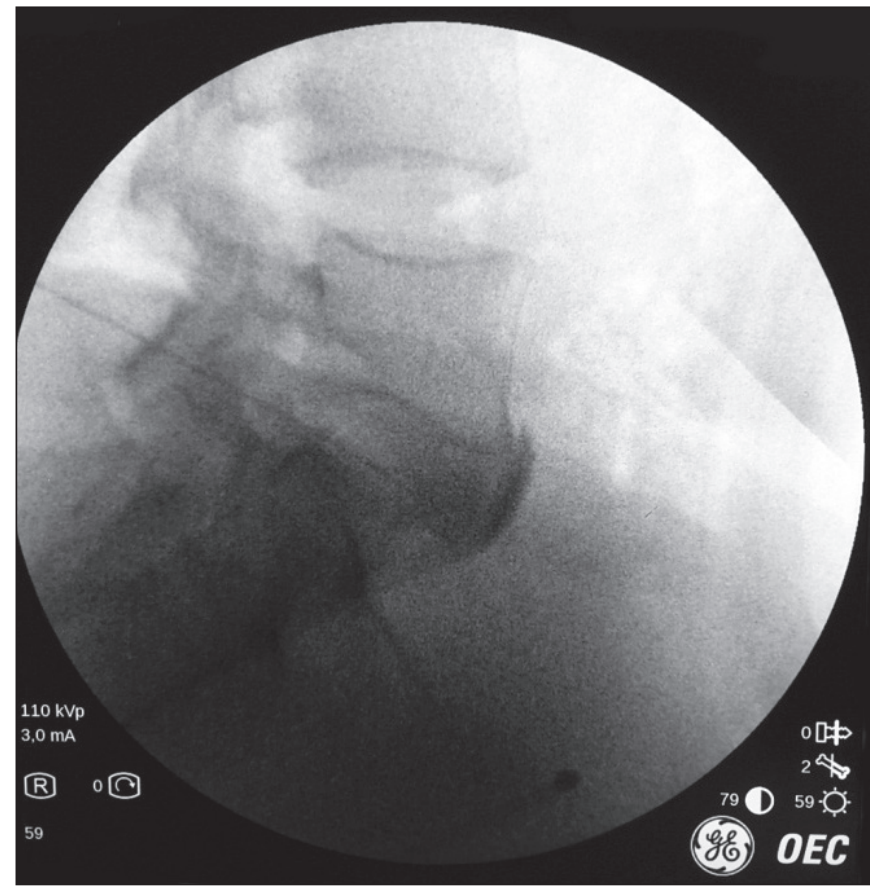

Figure 2: Final needle position and spread of contrast in lateral view.

ments before the procedure, at the first month, third month, and sixth month after the procedure. Statistical significance level was accepted as 0.05 and Statistical Package for Social Sciences (IBM SPSS, Version 15.0, Chicago, IL.) was used for the analysis.

\section{RESULTS}

The socio-demographic characteristics of the patients are shown in Table I.

The causes of chronic pain in the study patients were, respectively, endometriosis (6 patients, 15\%), pelvic organ malignancy (bladder, ovarian, rectum, colon cancer, 19 patients, $47.5 \%$ ), interstitial cystitis (9 patients, $22.5 \%$ ), previous prostate surgery (postprostatectomy pain, 6 patients, 15\%) (Table II).

While the mean VAS before the procedure was 8.8 , the VAS at 1 month, 3 months, and 6 months after the procedure were recorded as 3.7, 2.2, and 1.1, respectively (Table III). All of the VAS changes were statistically significant $(p<0.05)$.

The mean ODI score of the patients before the procedure was recorded as $46.0 \%$ (severe disability).

The ODI score was recorded as $22.0 \%$ in the first month follow-up, $10.5 \%$ in the third-month follow-up, and $3 \%$ in the sixth-month follow-up (Table IV). All of the changes in the ODI score were statistically significant $(p<0.05)$.
Table I: Patients' Characteristics

\begin{tabular}{lcc} 
& Mean \pm SD & Median (min-max) \\
Age (year) & $53.1 \pm 11.9$ & $52.5(35-78)$ \\
\hline Height $(\mathrm{cm})$ & $169.6 \pm 5.2$ & $170.0(160-180)$ \\
\hline Weight $(\mathrm{kg})$ & $72.5 \pm 7.3$ & $73.5(55-85)$ \\
\hline Body mass index (BMI) & $24.7 \pm 3.8$ & $25.7(19-29.7)$ \\
\hline
\end{tabular}

SD: Standart deviation; min: Minimum; max: Maximum; med: Median.

Table II: Causes of Chronic Pelvic Pain in Patients

\begin{tabular}{lrc} 
Cause of chronic pelvic pain & $\mathbf{n}$ & \% \\
Endometriosis & 6 & 15.0 \\
\hline Interstitial cystitis & 9 & 22.5 \\
\hline Canser & 19 & 47.5 \\
\hline Post-prostatectomy pain & 6 & 15 \\
\hline Total & 40 & 100 \\
\hline
\end{tabular}

n: Number of patients.

Table III: VAS Changes

\begin{tabular}{lll}
$\mathbf{n}=40$ & $\begin{array}{c}\text { Median } \\
\text { (min-max) }\end{array}$ & p \\
\hline Before the procedure & $9.0(7.0-10.0)$ & \\
\hline Post-procedure & & \\
\hline 1 month & $4.0(2.0-6.0)^{*}$ & $\mathrm{p}=0.000$ \\
\hline 3 months & $2.0(1.0-4.0)^{*}$ & $\mathrm{p}=0.000$ \\
\hline 6 months & $1.0(0.0-1.0)^{*}$ & $\mathrm{p}=0.000$ \\
\hline
\end{tabular}

${ }^{*} p<0.05$ (VAS score changes before and after the procedure were analyzed using Friedman's Two-Way test); min: minimum; max: maximum; VAS: Visual Analogue Scale.

Table IV: ODI Score Changes

\begin{tabular}{lcc}
$\mathbf{n}=40$ & $\begin{array}{c}\text { Median } \\
(\mathbf{m i n}-\max )\end{array}$ & $\mathbf{p}$ \\
\hline Before the procedure & $42.5(39.0-60.0)$ & \\
\hline Post-procedure & & \\
\hline 1 month & $20.0(17.0-30.0)^{*}$ & $\mathrm{p}=0.016$ \\
\hline 3 months & $10.0(6.0-20.0)^{*}$ & $\mathrm{p}=0.000$ \\
\hline 6 months & $3.0(1.0-8.0)^{*}$ & $\mathrm{p}=0.000$ \\
\hline
\end{tabular}

${ }^{*} p<0.05$ (VAS changes before and after the procedure were analyzed using Friedman's Two-Way test); min: minimum; max: maximum; ODI: Oswestry Disability Index.

\section{DISCUSSION}

Chronic pelvic pain is a problem that affects both sexes, reduces the patient's quality of life and limits their functional capacity. In pelvic pain; in addition to urological, gynecological, musculoskeletal causes, gastrointestinal system pathologies, psychiatric and neurological diseases may be included in the etiology. However, in many cases, the cause of pain 
cannot be found and it is classified as chronic pelvic pain syndrome (7).

In our study, the mean age was 53 and $62.5 \%$ (25 patients) of the patients were women. This is consistent with the data in the literature (8).

Chronic pelvic pain is the most common indication for referral to women's health services, accounting for $20 \%$ of all outpatient appointments in the United States alone (9). The most common causes of chronic pelvic pain in women are endometriosis, pelvic inflammatory diseases, adnexal masses, and neuropathic conditions after previous surgery (8). The causes of pelvic pain in our study were endometriosis (6 patients), malignancy (11 patients), and interstitial cystitis (8 patients) (a total of 25 female patients). It has been shown in some studies that there is an inverse relationship between endometriosis and body mass index $(10,11)$. Although the mean BMI of 6 endometriosis patients in our study was $24.5,5$ has a BMI>25 (pre-obese). This result may be related to the small number of study patients.

Colorectal cancer is the most common pelvic malignancy in both sexes (12).

Forty seven point five percent of the study patients (19 patients) were followed up with the diagnosis of cancer. Among the pelvic malignancies in women, ovarian cancer ranks first (13). It was determined that 5 of 25 female patients in our study were diagnosed with ovarian cancer, 3 with colorectal cancer and 3 with endometrial cancer.

Prostate cancer is the most common pelvic malignancy in men (14). In our study, the number of male patients diagnosed with malignancy was 8 , and the cause of pain was prostate cancer in 4 patients and colorectal cancer in 4 patients.

With the progression of the malignancy stage, pelvic pain can become even more debilitating, limiting functional status and severely reducing quality of life. It is estimated that approximately $60 \%$ of patients with malignancy develop chronic pain, and adequate pain control is not achieved in $56 \%-82 \%$ of these patients (15). Chronic pain can manifest in many ways, including mass effect from the primary tumor, invasion of nearby neurovascular structures, and metastatic conditions to local and/or distant sites. Also, as improvements in diagnosis and treatments occur, the number of cancer survivors with post-treatment chronic pain syndrome, such as radiation and chemotherapy-induced neuropathies, is steadily increasing (15). In neuropathic pain (patients complain of burning, tingling, stinging), antiepileptics (gabapentin, pregabalin), tricyclic antidepressants (amitriptyline) or selective serotonin reuptake inhibitors can be added to the treatment.
Treatment methods of chronic pelvic pain syndrome include physical, pharmacological, surgical and interventional procedures (1). Chronic pelvic pain syndrome due to pelvic organ tumors can sometimes be resistant to conservative treatment. Superior hypogastric plexus blocks, neurolytic blocks, and surgical methods are applied in cases where efficacy cannot be achieved with conservative treatments.

Oscar A de Leon-Casasola et al. reported that they achieved successful pain control during a 1-year follow-up in 26 patients with colorectal, gynecological, and genitourinary cancer who underwent superior hypogastric plexus neurololytic block (16).

In our study, 19 patients diagnosed with pelvic organ cancer underwent chemical neurolysis with $6 \%$ phenol $(5 \mathrm{~mL} 6 \%$ phenol $+2 \mathrm{~mL} 0.5 \%$ bupivacaine) after the diagnostic block. After the neurolytic block, it was determined that effective analgesia was provided in 19 patients during the follow-up period.

The superior hypogastric plexus is located to the left of the midline, just below the aortic bifurcation, in front of the L5-S1 vertebra and the L5-S1 disc. It contains afferent nociceptive and postganglionic parasympathetic fibers. Neuropathic pains originating from the descending colon and sigmoid, rectum, vagina, bladder, prostate, urethra, testicles, uterus and ovaries, pain of gynecological origin: endometriosis, adhesions or chronic inflammation, pain due to interstitial cystitis, pain after prostatectomy, pain due to pelvic malignancies are among the indications for application superior hypogastric plexus block (6). Superior hypogastric plexus block is an effective method in the treatment of chronic pelvic pain. Effective control of non-malignant pain can be achieved by injection of a mixture of steroids and local anesthetics (17). Neurolytic blockade can be performed in patients with malignancy who benefit from the block (16).

Percutaneous superior hypogastric plexus blockade, first described by Plancarte, can be performed classically and transdiscally (6). In our clinic, the classical approach is applied with a $22 \mathrm{G}$ needle. Lumbar 5 nerve root contact and internal iliac artery puncture are possible complications of this technique (6). Technical difficulties that occur in patients with osteophytes, post procedure discitis, herniation are the disadvantages of the transdiscal approach. These complications are not seen in the classical approach $(18,19)$.

Successful block was applied with the classical approach in all 40 patients included in our study. Superior hypogastric plexus blockade can also be performed with computerized tomography. Although good visualization of vascular and soft tissue structures is one of the advantages of computed tomography, its high radiation exposure is a disadvantage (18). In our clinic, the procedure is performed with fluoroscopy. 
In our study, $0.25 \%$ bupivacaine $5 \mathrm{~mL}+8 \mathrm{mg}$ dexamethasone mixture was applied in the superior hypogastric plexus block. Dexamethasone particles are 5-10 times smaller than red blood cells with a diameter of $0.5 \mu \mathrm{m}$. It is soluble in water. It has no aggregation feature. When dexamethasone is used in the same syringe with local anesthetics, its viscosity increases slightly, but its aggregation does not increase (20). Bupivacaine is the preferred local anesthetic with a longer duration of action (21).

The management of chronic pelvic pain is often complex with limited evidence-based treatment options. Detailed anamnesis and physical examination of the patients are of great importance in revealing the possible etiology. It would be rational to plan the necessary laboratory tests, imaging methods and other special examinations in line with the data obtained.

Our study has several limitations. First, the number of patients included in the study was low. Second, our study design was retrospective. Third, data on the patients' clinical information and oral drug use was scarce.

\section{CONCLUSION}

In the treatment of chronic pelvic pain, superior hypogastric plexus blockage is an effective therapy option. The results of blockade performed with a mixture of local anesthetic and steroid with the classical approach, accompanied by fluoroscopy, are satisfactory. Patients who receive temporary pain relief with diagnostic block in chronic pelvic pain caused by cancer can benefit from neurolytic block.

\section{AUTHOR CONTRIBUTIONS}

\section{Conception or design of the work: DA, IA}

Data collection: DA, UA

Data analysis and interpretation: DA, UA

Drafting the article: DA

\section{Critical revision of the article: IA}

All authors (DA, UA, IA) reviewed the results and approved the final version of the manuscript.

\section{REFERENCES}

1. Mansoor MA, Ammar M. Female pelvic pain. In: Pak DJ, RY, J, Krishna BS, (eds). Interventional management of chronic visceral pain syndromes. St. Louis, Missouri: Elsevier Inc, 2021;17-18.

2. Yosef A, Abdel Ghaffar A, Al-Hussaini T, Abdellah MS, Cua G, Bedaiwya MA. Chronic pelvic pain: Pathogenesis and validated assessment. Middle East Fertility Society Journal 2016;21(4):205-21.
3. Ahangari A. Prevalence of chronic pelvic pain among women: An updated review. Pain Physician 2014;17(2):141-7.

4. Kanazi GE, Perkins FM, Thakur R, Dotson E. New technique for superior hypogastric plexus block. Reg Anesth Pain Med 1999;24:473-6.

5. Patt R, Plancarte R. Superior hypogastric plexus block: A new therapeuti capproach for pelvic pain. In: Waldmann SD, (ed). Interventional pain management. Philadelphia: WB Saunders, 2001;528-34.

6. Erdine S. Superior hypogastric plexus block. In: Erdine S, (ed). Interventional Methods in Algology. Istanbul: Nobel Tip Kitabevleri, 2012;439-47.

7. Chronic pelvic pain: ACOG practice bulletin, number 218 . Obstet Gynecol 2020;135(3):98-109.

8. Alappattu MJ, Bishop MD. Psychological factors in chronic pelvic pain in women: Relevance and application of the fearavoidance model of pain. Phys Ther 2011;91(10):1542-50.

9. Ayorinde AA, Bhattacharya S, Druce KL, Jones GT, Macfarlane GJ. Chronic pelvic pain in women of reproductive and postreproductive age: A population-based study. Eur J Pain 2017;21(3):445-55.

10. Nnoaham KE, Hummelshoj L, Webster P, et al. Impact of endometriosis on quality of life and work productivity: A multicenter study across ten countries. Fertil Steril 2011;96(2):366-73.

11. Holdsworth-Carson SJ, Dior UP, Colgrave EM, et al. The association of body mass index with endometriosis and disease severity in women with pain. J Endometriosis and Pelvic Pain Disord 2018;10:79-87.

12. Rawla P, Sunkara T, Barsouk A. Epidemiology of colorectal cancer: Incidence, mortality, survival, and risk factors. Prz Gastroenterol 2019;14(2):89-103.

13. Ovarian Cancer Statistics | How Common is Ovarian Cancer. Available from: https://www.cancer.org/cancer/ ovariancancer/about/key-statistics.html. [Accessed 30 May, 2020]

14. Rawla P. Epidemiology of prostate cancer. World J Oncol 2019;10(2):63-89.

15. Rigor Sr BM. Pelvic cancer pain. J Surg Oncol 2000;75(4):280300.

16. de Leon-Casasola OA, Kent E, Lema MJ. Neurolytic superior hypogastric plexus block for chronic pelvic pain associated with cancer. Pain 1993;54(2):145-51.

17. Stewart JK, Patetta MA, Burke CT. Superior hypogastric nerve block for pain control after uterine artery embolization: Effect of addition of steroids on analgesia. J Vasc Interv Radiol 2020;31(6):1005-9.

18. Michalek P, Dutka J. Computed-tomography guided anterior approach to the superior hypogastric plexus for non cancer pelvic pain: A report of two cases. Clin J Pain 2005;21(6):5536. 
19. Gamal G, Helaly M, Labib YM. Superior hypogastric block: Transdiscal versus classic posterior approach in pelvic cancer pain. Clin J Pain 2006;22(6):544-7.

20. Erdine S. Drugs used in interventional methods. In: Erdine $S$, (ed). Interventional methods in algology. Istanbul: Nobel Tip Kitabevleri, 2012;58-60.

21. Karina G, Michael L, Vikram BP. Ganglion impar blockade. In: Alan DK, Frank JEF, Joshua AH, (eds). Essentials of interventional techniques in managing chronic pain, cham. Springer International Publishing AG, 2018;586-7. 